\title{
BIO- AND AIR-TOLERANT CARBON-CARBON BOND FORMATIONS VIA ORGANOMETALLIC RUTHENIUM CATALYSIS
}

\author{
Louis AdriAENSSENS ${ }^{1}$, Lukáš SEVERA ${ }^{2}$, Jan VÁVRA ${ }^{3}$, Tereza ŠÁlOVÁ ${ }^{4}$, Jakub HÝVL ${ }^{5}$, \\ Martina Č́̌̌̌KOVÁ ${ }^{6}$, Radek POHL ${ }^{7}$, David ŠAMAN ${ }^{8}$ and Filip TEPLÝ ${ }^{9, *}$ \\ Institute of Organic Chemistry and Biochemistry, Academy of Sciences of the Czech Republic, v.v.i., \\ Flemingovo nám. 2, 16610 Prague 6, Czech Republic; e-mail: ${ }^{1}$ adriaenssens@uochb.cas.cz, \\ 2 severa@uochb.cas.cz, ${ }^{3}$ vavra@uochb.cas.cz, ${ }^{4}$ salova.tereza@seznam.cz, ${ }^{5}$ hyvl@uochb.cas.cz, \\ ${ }^{6}$ cizkova@uochb.cas.cz, ${ }^{7}$ pohl@uochb.cas.cz, ${ }^{8}$ saman@uochb.cas.cz, ${ }^{9}$ teply@uochb.cas.cz
}

Received April 17, 2009

Accepted April 22, 2009

Published online June 26, 2009

Dedicated to Dr. Alfred Bader on the occasion of his 85th birthday in recognition of his outstanding contributions as a chemist, enterpreneur, and benefactor.

Selected [2+2+2] cycloadditions, alkene-alkyne coupling and fusion of enyne with diazo compound, all triggered by an artificial organometallic ruthenium catalyst are demonstrated to proceed under ambient aerobic aqueous conditions in presence of bodily fluids or cell lysate. To the best of our knowledge, these are the first examples of bio- and air-tolerant $\mathrm{C}-\mathrm{C}$ bond formation catalyzed by an artificial organometallic compound.

Keywords: Ruthenium; Organometallic catalysis; C-C coupling; $[2+2+2]$ Cycloadditions; Alkene-alkyne coupling; Enyne-diazocompound fusion; Alkynes; Arenes; Heterocycles; Nitrogen-based organic cations; N-heteroaromatic cations; Helical structures; Helquat; Bio-, air-, and water-tolerant transformations; E. coli cell lysate; Human serum; Bioorthogonal reactions; Non-coded biocompatible chemistry.

Construction of carbon-carbon $(\mathrm{C}-\mathrm{C}$ ) bonds is the essence of organic chemistry ${ }^{1}$. In this respect, catalysis by organometallics (compounds with carbon-metal bonds) has become a powerful tool ${ }^{2}$. However, catalytic manifolds involving C-M bonds are widely viewed as incompatible with water, air, thiols, and organic electrophiles ${ }^{3-5}$. Consequently, the general lack of robust catalytic processes supported under aerobic aqueous physiological conditions represents a fundamental obstacle in the application of organometallic catalysis towards in situ synthesis in chemical biology, diagnostics, and therapeutics. Referring to this seldom discussed synthetic aspect of bioorganometallic chemistry ${ }^{6}$, notable examples of $\mathrm{C}-\mathrm{H}$ (ref. ${ }^{7}$ ), C-N (ref. ${ }^{8}$ ), and $\mathrm{C}-\mathrm{S}$ (ref. ${ }^{6}$ ) bond formations catalyzed by organometallics under aerobic 
conditions in complex cellular media have been reported. In this vein, the identification of organometallic processes that form $\mathrm{C}-\mathrm{C}$ bonds under physiological conditions represents a particularly important challenge ${ }^{9-11}$.

\section{RESULTS AND DISCUSSION}

Here, we show that $\mathrm{C}-\mathrm{C}$ bond formation can be performed using an artificial ruthenium organometallic catalyst in presence of aqueous aerobic media such as bodily fluids or cell lysate under mild conditions. Recently, Meggers and Streu effected the uncaging of amines from the corresponding allylcarbamates in living cells using commercially available catalyst $\mathbf{1}$ (ref. ${ }^{6}$ ). In other work directed towards organic synthesis in bio-media, the groups of Bertozzi and Sharpless have shown alkyne functionality to be significantly biorthogonal ${ }^{12,13}$. Inspired by these findings, we speculated that bio-tolerant $\mathrm{C}-\mathrm{C}$ bond forming processes could be found among the rich set of known alkyne-based transformations catalyzed by $\mathbf{1}$ (ref. ${ }^{14}$ ). We observed that $[2+2+2]$ cycloaddition of dimethyl acetylenedicarboxylate (2) using catalyst 1 ( 1 mole $\%)^{15}$ was not only air-tolerant ${ }^{16}$ but also proceeded in presence of water without any added organic co-solvent (Scheme 1,

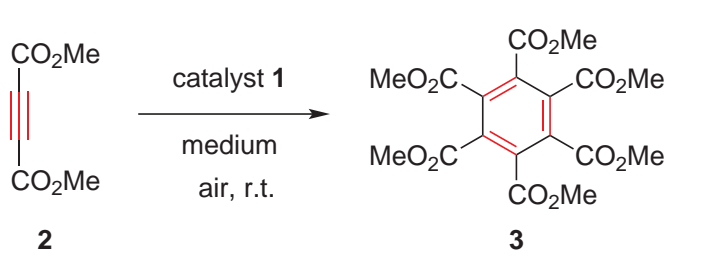

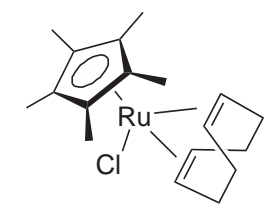

Catalyst, 1

\section{SCheme 1}

TABLE I

Bio- and air-tolerant $[2+2+2]$ cycloaddition of alkyne $\mathbf{2}^{\mathrm{a}}$

\begin{tabular}{llcll}
\hline Entry & Catalyst 1, \% & Time, h & Medium & Yield, \% $^{\mathrm{b}}$ \\
\hline 1 & 1 & 5.5 & $\mathrm{H}_{2} \mathrm{O}$ & $7^{\mathrm{c}}$ \\
2 & 5 & 25 & Rattus norveg. urine & 72 \\
3 & 5 & 4 & E. coli cell lysate & 76 \\
4 & 0 & 20 & E. coli cell lysate & $0^{\mathrm{c}, \mathrm{e}}$ \\
5 & 5 & 22 & fetal bovine serum & 59 \\
6 & 5 & 24 & human serum & \\
\hline
\end{tabular}

a Medium (1 ml), 2 (100 $\mu \mathrm{l}, 0.81 \mathrm{mmol}) .{ }^{\mathrm{b}}$ Isolated yields of $3 .{ }^{\mathrm{c}} 2 \mathrm{ml}$ of medium used. ${ }^{d}$ From Rattus norvegicus adult males. ${ }^{e}$ Starting material $\mathbf{2}$ was recovered in $56 \%$ yield. ${ }^{f}$ From male, age 31. 
Table I, entry 1$)^{17}$. Under these mild aerobic conditions, the starting material was consumed within $5.5 \mathrm{~h}$ and hexamethyl mellitate $\mathbf{3}$ was isolated in $76 \%$ yield. Notably, the reaction progressed to give similarly good isolated yields when performed with urine of Rattus norvegicus, cell lysate from Escherichia coli, fetal bovine serum, and human serum (entries 2-6). To the best of our knowledge, this is the first example of C-C bond formation catalyzed by an artificial organometallic compound in the presence of air and bodily fluids or cell lysate.

The study was extended to include $[2+2+2]$ cycloaddition affording

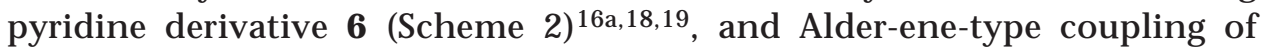
alkyne $\mathbf{7}$ with allyl alcohol (8) ${ }^{16 a, 20,21}$, to give a mixture of aldehydes $\mathbf{9}$ and 10 (Scheme 3). Of note is that aldehyde functionality is generated in this process. Such a feature might be further explored in the context of the follow-up reactivity profile of aldehydes in living systems ${ }^{22}$. Product $\mathbf{9}$ is present as a mixture of the open chain aldehyde $9 a$ and its cyclic seven-membered hemiacetal isomer $\mathbf{9 b}$ (9a:9b 75:25). Interestingly, synthesis of $\mathbf{9}$ thus represents organometallic assembly of a carbon framework reminiscent of aldoheptose in a bio-relevant environment in situ.

SCHEME 2
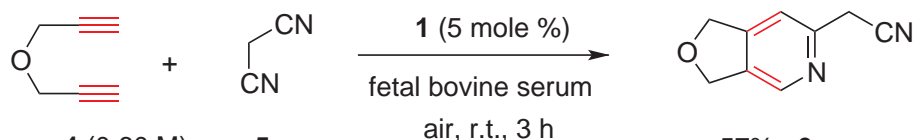

$57 \% 6$
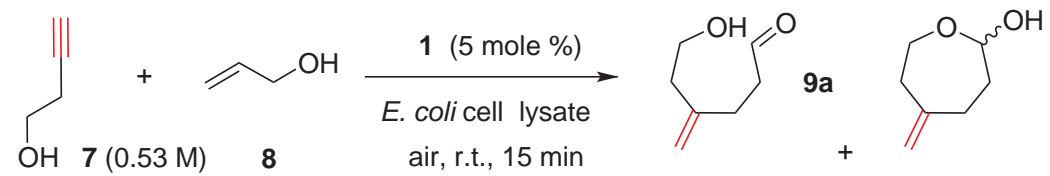

$9 b$

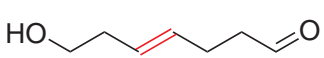

10

SCHEME 3

$58 \%\left(\begin{array}{ll}9: 10 & 7: 3)\end{array}\right.$

An example of enyne-diazo compound fusion to give bicyclic cyclopropanes $\mathbf{1 3}$ and $\mathbf{1 4}$ further expands the scope of bio-tolerant tran sformations catalyzed by $\mathbf{1}$ (Scheme 4) $16 a, 23,24$. This transformation proceeds remarkably fast with all the media tested ( $E$. coli cell lysate, combined yield of $\mathbf{1 3}$ and 14 is $60 \%$; Rattus norvegicus urine, $57 \%$; human serum, $45 \%$ ).

Heterogeneous catalysis and transformations taking place 'on water' $5 \mathrm{c}$ cannot be excluded as substrates, products and also the catalyst $\mathbf{1}$ in examples in Table I and Schemes 2-4 were partly insoluble under the reaction 
conditions presented. Therefore, we next turned to a transformation where better homogeneity of the reacting mixture is ensured. Specifically, we examined the feasibility of synthesis of our novel water-soluble helical extended diquat (helquat) ${ }^{25}$ in E. coli cell lysate with an added $1 \%$ acetone to aid solubilization of the catalyst (Scheme 5).

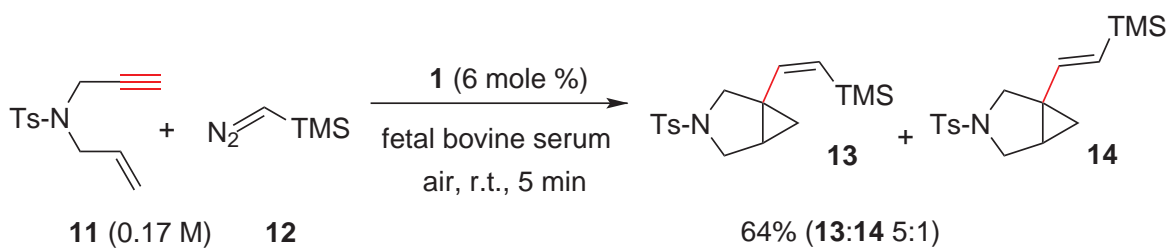

SCHEME 4
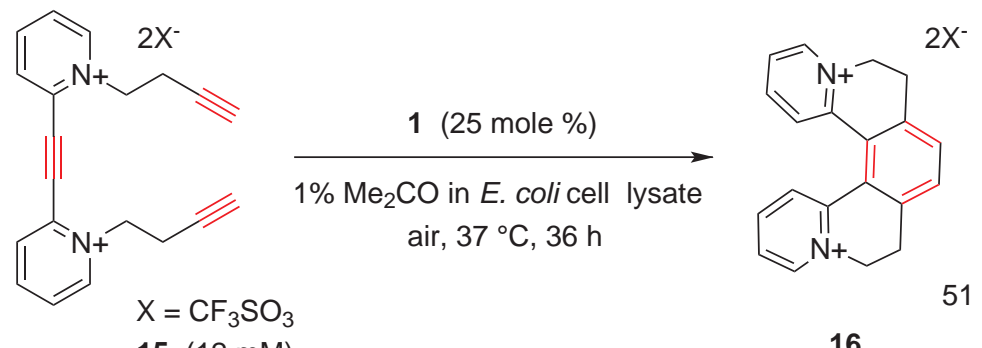

$51 \%$

$15(12 \mathrm{mM})$

16

SCHEME 5

As judged by NMR analysis of the evaporated reaction mixture, progressive disappearance of the peaks corresponding to triyne $\mathbf{1 5}$ and emergence of peaks diagnostic of helquat $\mathbf{1 6}$ demonstrates the feasibility of this process under aerobic bio-relevant conditions (Fig. 1). Increase in yield from $33 \%$ after $2.5 \mathrm{~h}$ to $51 \%$ after $36 \mathrm{~h}$, demonstrates that the $\left(\mathrm{C}_{5} \mathrm{Me}_{5}\right)$ Ru-based organometallic catalyst stays active for extended periods in this medium ${ }^{26}$.

Notably, the reaction proceeds effectively even in the presence of considerable amounts of bovine serum albumin, a protein known for its promiscuous binding profile (Fig. 2) 27 .

Potentially, a reaction proceeding via organometallic intermediates might be viewed as an entry to a collection of species with potential bioactivity (Fig. 3). The possibility of searching through such species generated in situ in presence of biological targets contained in the reaction medium, might allow for investigation of binding or reactive events otherwise difficult or even impossible to realize. Such an approach seems particularly attractive in light of the fact that $\left(\mathrm{C}_{5} \mathrm{H}_{5}\right) \mathrm{Ru}$ and other Ru-arene organometallics have been shown to be potent and selective bioactive entities ${ }^{28}$. 

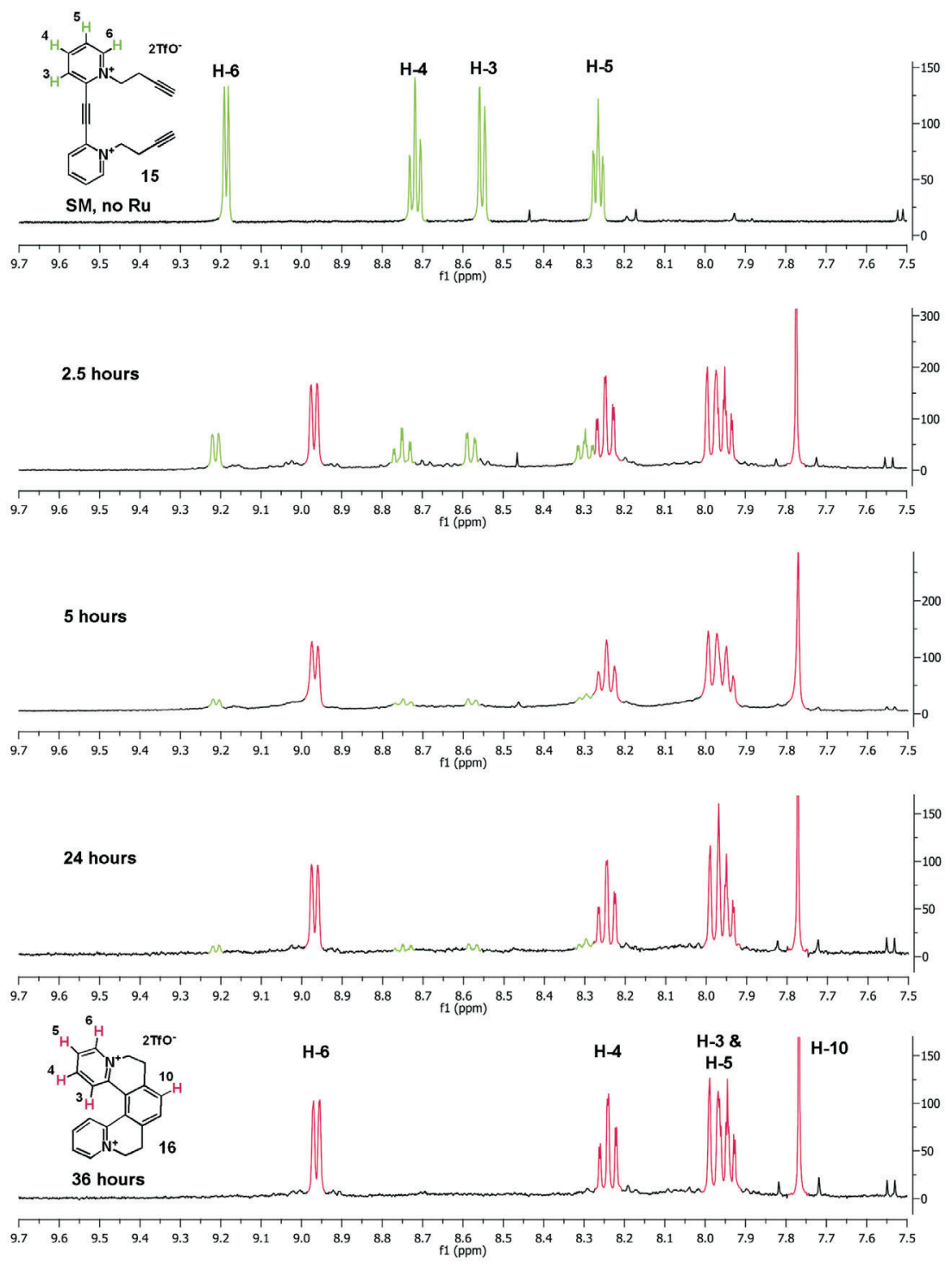

FIG. 1

${ }^{1} \mathrm{H} N M R\left(400 \mathrm{MHz}, \mathrm{D}_{2} \mathrm{O}\right)$ monitored progression of Ru-catalyzed cycloaddition of $\mathbf{1 5}$ in E. coli cell lysate (Scheme 5). From solvation of starting material $\mathbf{1 5}$ in E. coli cell lysate before addition of catalyst $\mathbf{1}$ (top panel) to end of reaction after $36 \mathrm{~h}$ as judged by disappearance of $\mathbf{1 5}$ (bottom panel) 
In summary, we have presented evidence that formation of C-C bonds via ruthenium organometallic catalysis can be achieved in the presence of bio-relevant media such as fetal bovine serum or E. coli cell lysate under aerobic ambient conditions. This will be of conceptual and practical interest for organometallic carbon framework construction targeted towards bio-applications including chemical biology, diagnostics, and therapeutics.

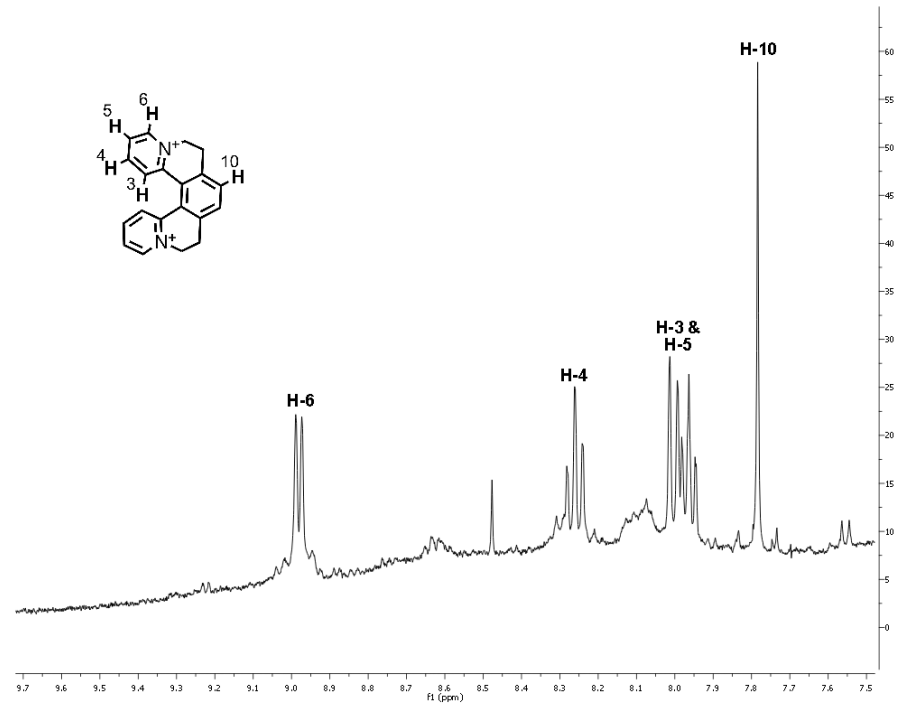

FIG. 2

${ }^{1} \mathrm{H} N M R\left(400 \mathrm{MHz}, \mathrm{D}_{2} \mathrm{O}\right)$ of reaction mixture from transformation $\mathbf{1 5} \rightarrow \mathbf{1 6}$ in the presence of bovine serum albumin and $\mathrm{E}$. coli cell lysate

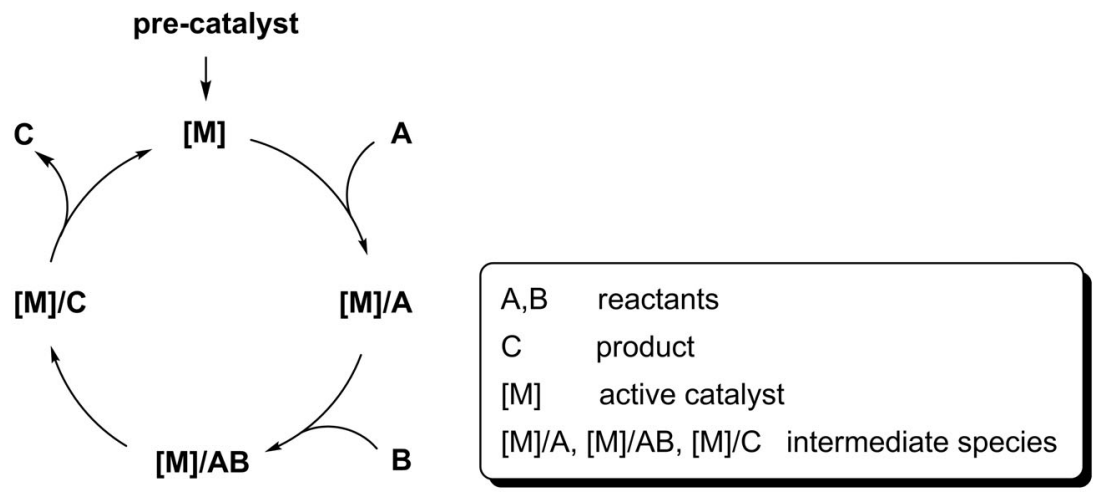

FIG. 3

An un-natural organometallic reaction in bio-relevant media might be viewed as an entry to a collection of species with potential bioactivity 


\section{EXPERIMENTAL}

Unless otherwise noted, all reactions were carried out under aerobic conditions with no efforts taken to exclude air and moisture. Liquids and solutions were added via needle and syringe unless otherwise stated. Thin-layer chromatography (TLC) analysis was performed on silica gel plates (Silica gel $60 \mathrm{~F}_{254}$-coated aluminium sheets, Merck, cat. No. 1.05554.0001) and visualized by UV (UV lamp 254/365 nm, Spectroline ${ }^{\circ}$ Model ENF - 240C/FE) and, either chemical staining with $\mathrm{KMnO}_{4}\left[\mathrm{KMnO}_{4}\left(1 \%\right.\right.$ aq.), $\mathrm{Na}_{2} \mathrm{CO}_{3}(2 \%$ aq.) $]$, or $\mathrm{Ce}\left(\mathrm{SO}_{4}\right)_{2}\left[\mathrm{Ce}\left(\mathrm{SO}_{4}\right)_{2} \cdot 4 \mathrm{H}_{2} \mathrm{O}\right.$ (1\%), $\mathrm{H}_{3} \mathrm{P}\left(\mathrm{MO}_{3} \mathrm{O}_{10}\right)_{4}(2 \%)$ in sulfuric acid (10\% aq.)]. TLC analysis of dications was achieved using Stoddart's magic mixture ${ }^{29}\left(\mathrm{MeOH}: \mathrm{NH}_{4} \mathrm{Cl}_{\text {aq }}(2 \mathrm{M}): \mathrm{MeNO}_{2} \quad 70: 20: 10\right)$ as eluent on silica gel plates. Flash chromatography was performed on silica gel 60 (Fluka, cat. No. 60741) with the indicated eluent. All dilutions performed to determine the yield of $\mathbf{1 6}$ were performed with volumetric glassware and/or Hamilton Microliter ${ }^{\mathrm{TM}}$ syringes.

\section{Materials}

Unless otherwise stated, all starting materials and reagents were obtained from commercial suppliers and used without further purification. Demineralized water obtained from the Water Purification Facility at the Institute of Organic Chemistry and Biochemistry, Academy of Sciences of the Czech Republic was used unless otherwise stated. Demineralization was accomplished via filtration through ion exchange columns (Lewatit S100 for catex column, Lewatit MP500 for anex column) in a demineralization ion exchange station type ID-PP and ID-KP (Kavalier, Votice, Czech Republic).

Rattus norvegicus urine. The urine from several male rats (Rattus norvegicus species, Wistar, supplier: Bio-Test s.r.o. Konárovice, Czech Republic) was pooled and kept frozen $\left(-20{ }^{\circ} \mathrm{C}\right)$ until further use. Before an experiment, it was thawed in a $30{ }^{\circ} \mathrm{C}$ water bath.

Escherichia coli cell lysate. Escherichia coli $\mathrm{DH} 5 \alpha$ transformed with plasmid pET24a (Novagen, cat. No. 69749-3) were grown in LB broth (Sigma, L3022) containing kanamycin (40 $\mu \mathrm{g} / \mathrm{ml}$, Fluka 60615$) .40 \mathrm{ml}$ of LB media were inoculated with $4 \mu \mathrm{l}$ of saturated culture and grown overnight at $37{ }^{\circ} \mathrm{C}$ and $220 \mathrm{rpm}$. The culture was spun down at $3500 \mathrm{~g}$ for $15 \mathrm{~min}$ and the pellet was resuspended in $10 \mathrm{ml}$ of phosphate buffered saline (PBS) and sonicated $(6 \times 1 \mathrm{~min}$ at $3-\mathrm{min}$ intervals). The crude lysate was then spun down at $10000 \mathrm{~g}$ for $30 \mathrm{~min}$ at $4{ }^{\circ} \mathrm{C}$ and the supernatant was decanted. The solution was stored at $-20{ }^{\circ} \mathrm{C}$. Before an experiment, it was thawed in a $30{ }^{\circ} \mathrm{C}$ water bath. The residue content of the material was $35 \mathrm{mg} / \mathrm{ml}$.

Fetal bovine serum (FBS). FBS was purchased from Invitrogen-Gibco (cat. No. 10270-106). Before use, FBS was heated at $65{ }^{\circ} \mathrm{C}$ for $30 \mathrm{~min}$ to inactivate the complement system. The residue content of the material was $30 \mathrm{mg} / \mathrm{ml}$.

Human serum. One of the authors (male, 31) donated the blood (B negative blood type). All blood analysis data were within normal range and HIV $1+2$ negative. The serum was obtained by centrifugation of the whole blood. Serum was stored in the freezer $\left(-20^{\circ} \mathrm{C}\right)$ and thawed before use in a $30^{\circ} \mathrm{C}$ bath. The residue content of the material was $100 \mathrm{mg} / \mathrm{ml}$.

\section{Hexamethyl Benzene-1,2,3,4,5,6-hexacarboxylate (3). General Procedure}

Dimethyl acetylenedicarboxylate $\mathbf{2}$ was added dropwise via Hamilton syringe under open flask conditions to a suspension of $[\mathrm{Cp} * \mathrm{Ru}(\mathrm{cod}) \mathrm{Cl}] \mathbf{1}$ in the described medium. The reaction flask was closed with a stopper to prevent evaporation and the reaction mixture stirred for 
the described time at room temperature (r.t.). Formation of the product and consumption of the starting material was detected by TLC (petroleum ether:ethyl acetate 50:50, product $R_{F} 0.29$, starting material $R_{F}$ 0.85). The reaction mixture was diluted with water and extracted with ethyl acetate $(5 \times)$. The combined organic phases were dried over anhydrous $\mathrm{Na}_{2} \mathrm{SO}_{4}$. The mixture was filtered and the solvent was removed in vacuo to give crude product which was purified by flash chromatography on silica gel (petroleum ether:ethyl acetate 60:40). Hexamethyl benzene-1,2,3,4,5,6-hexacarboxylate $\mathbf{3}$ was obtained as colorless crystals. The spectroscopic characterization data are in agreement with the literature ${ }^{17}$.

Table I, entry 1. Using dimethyl acetylenedicarboxylate $2(100 \mu \mathrm{l}, 115.6 \mathrm{mg}, 0.813 \mathrm{mmol}$, 1 equiv.), [Cp*Ru(cod)Cl] 1 (3.5 mg, $9.2 \mu \mathrm{mol}, 1$ mole \%), water ( $2 \mathrm{ml}$ ) as the medium, and a reaction time of $5.5 \mathrm{~h}$, hexamethyl benzene-1,2,3,4,5,6-hexacarboxylate $\mathbf{3}$ was obtained as colorless crystals in $76 \%$ yield $(88.3 \mathrm{mg}, 0.207 \mathrm{mmol})$.

Table I, entry 2. Using dimethyl acetylenedicarboxylate 2 (100 $\mu \mathrm{l}, 115.6 \mathrm{mg}, 0.813 \mathrm{mmol}$, 1 equiv.), [Cp*Ru(cod)Cl] 1 (15.5 mg, $40.8 \mu \mathrm{mol}, 5$ mole \%), urine of Rattus norvegicus ( $1 \mathrm{ml}$ ) as the medium, and a reaction time of $25 \mathrm{~h}$, hexamethyl benzene-1,2,3,4,5,6-hexacarboxylate 3 was obtained as colorless crystals in $72 \%$ yield $(83.3 \mathrm{mg}, 0.195 \mathrm{mmol})$.

Table I, entry 3. Using dimethyl acetylenedicarboxylate 2 (100 $\mu \mathrm{l}, 115.6 \mathrm{mg}, 0.813 \mathrm{mmol}$, 1 equiv.), [Cp*Ru(cod)Cl] 1 (15.5 mg, $40.8 \mu \mathrm{mol}, 5$ mole \%), E. coli DH5 $\alpha$ cell lysate ( $1 \mathrm{ml})$ as the medium, and a reaction time of $4 \mathrm{~h}$, hexamethyl benzene-1,2,3,4,5,6-hexacarboxylate 3 was obtained as colorless crystals in $76 \%$ yield $(87.3 \mathrm{mg}, 0.205 \mathrm{mmol})$.

Table I, entry 4. Using dimethyl acetylenedicarboxylate 2 (100 $\mu \mathrm{l}, 115.6 \mathrm{mg}, 0.813 \mathrm{mmol}$, 1 equiv.), E. coli $\mathrm{DH} 5 \alpha$ cell lysate $(2 \mathrm{ml})$ as the medium, and a reaction time of $20 \mathrm{~h}$, but omitting [Cp*Ru(cod)Cl] 1 ( $0 \mathrm{mg}, 0 \mu \mathrm{mol}, 0$ mole \%), the starting material dimethyl acetylenedicarboxylate $\mathbf{2}$ was obtained as an oil in $72 \%$ yield $(83.3 \mathrm{mg}, 0.195 \mathrm{mmol})$. The spectroscopic characterization data are in agreement with that of the commercial sample.

Table I, entry 5. Using dimethyl acetylenedicarboxylate 2 (100 $\mu \mathrm{l}, 115.6 \mathrm{mg}, 0.813 \mathrm{mmol}$, 1 equiv.), [Cp*Ru(cod)Cl] 1 (15.5 mg, $40.8 \mu \mathrm{mol}, 5$ mole \%), fetal bovine serum ( $1 \mathrm{ml}$ ) as the medium, and a reaction time of $22 \mathrm{~h}$, hexamethyl benzene-1,2,3,4,5,6-hexacarboxylate 3 was obtained as colorless crystals in $59 \%$ yield $(68.6 \mathrm{mg}, 0.161 \mathrm{mmol})$.

Table I, entry 6. Using dimethyl acetylenedicarboxylate 2 (100 $\mu \mathrm{l}, 115.6 \mathrm{mg}, 0.813 \mathrm{mmol}$, 1 equiv.), [Cp*Ru(cod)Cl] 1 ( $15.6 \mathrm{mg}, 41.1 \mu \mathrm{mol}, 5$ mole \%), human serum ( $1 \mathrm{ml})$ as the medium, and a reaction time of $24 \mathrm{~h}$, hexamethyl benzene-1,2,3,4,5,6-hexacarboxylate 3 was obtained as colorless crystals in $52 \%$ yield $(60.2 \mathrm{mg}, 0.141 \mathrm{mmol})$.

\section{2-(1,3-Dihydrofuro[3,4-c]pyridin-6-yl)acetonitrile (6)}

Propargyl ether 4 (62 $\mu \mathrm{l}, 56.7 \mathrm{mg}, 0.602 \mathrm{mmol}, 1$ equiv.) was added dropwise over $15 \mathrm{~min}$ via Hamilton syringe to a stirring suspension of malononitrile 5 (61.6 $\mathrm{mg}, 0.932 \mathrm{mmol}$, 1.5 equiv.) and [Cp*Ru(cod)Cl] 1 (11.4 mg, $30 \mu \mathrm{mol}, 5$ mole \%) in fetal bovine serum ( $1 \mathrm{ml}$ ). The reaction mixture was then stirred at r.t. for $3 \mathrm{~h}$. Formation of the product was detected by TLC (hexanes:ethyl acetate 50:50, $R_{F}$ 0.18). The reaction mixture was diluted with water and extracted with DCM $(1 \times)$ and ethyl acetate $(3 \times)$. The organic fractions were combined and dried over anhydrous $\mathrm{Na}_{2} \mathrm{SO}_{4}$. The mixture was filtered and concentrated in vacuo to yield the crude product which was purified by flash chromatography on silica gel (hexanes: ethyl acetate 40:60). 2-(1,3-Dihydrofuro[3,4-c]pyridin-6-yl)acetonitrile 6 was obtained as a colorless amorphous solid in $57 \%$ yield $(55.0 \mathrm{mg}, 0.343 \mathrm{mmol})$. The spectroscopic characterization data are in agreement with the literature ${ }^{18}$. 
6-Hydroxy-4-methylenehexanal (9) and (E)-7-Hydroxyhept-4-enal (10)

Alkyne 7 (40 $\mu \mathrm{l}, 37.1$ mg, 0.529 mmol, 1 equiv.) was added dropwise via Hamilton syringe under open flask conditions to a stirring suspension of allyl alcohol 8 (110 $\mu \mathrm{l}, 93.8 \mathrm{mg}$, $1.614 \mathrm{mmol}, 3.1$ equiv.) and [Cp*Ru(cod)Cl] 1 (10.3 mg, $0.0271 \mathrm{mmol}, 5 \mathrm{~mole} \%)$ in E. coli $\mathrm{DH} 5 \alpha$ cell lysate $(1 \mathrm{ml})$. The reaction mixture was then stirred at r.t. for $15 \mathrm{~min}$. Formation of two products was detected by TLC (n-pentane:diethyl ether 50:50, product 9, $R_{F} \quad 0.23$; product 10, $\left.R_{F} 0.10\right)$. The reaction mixture was diluted with water and extracted with diethyl ether $(3 \times)$. The organic fractions were combined and dried over anhydrous $\mathrm{Na}_{2} \mathrm{SO}_{4}$. The mixture was filtered and concentrated in vacuo to give the crude product which was purified by flash chromatography on silica gel (n-pentane:diethyl ether 50:50). A 68:32 ratio of isomeric products $\mathbf{9}$ and $\mathbf{1 0}$ was obtained as a yellowish oil in 58\% yield (39.3 mg, $0.307 \mathrm{mmol}$ ). Repeated chromatography allowed samples of each isomer to be isolated (9 as a 76:24 ratio of the open chain and cyclic hemiacetal isomers $\mathbf{9 a}$ and $\mathbf{9 b}$ ). The spectroscopic characterization data are in agreement with the literature ${ }^{20}$.

(Z)-3-Tosyl-1-(2-(trimethylsilyl)vinyl)-3-azabicyclo[3.1.0]hexane (13) and

(E)-3-Tosyl-1-(2-(trimethylsilyl)vinyl)-3-azabicyclo[3.1.0]hexane (14)

(Trimethylsilyl)diazomethane $\mathbf{1 2}$ (110 $\mu \mathrm{l}, 2 \mathrm{~m}$ solution in diethyl ether, 0.220 mmol, 1.2 equiv.) and $[\mathrm{Cp} * \mathrm{Ru}(\mathrm{cod}) \mathrm{Cl}] \mathbf{1}$ (4 mg, $10.5 \mu \mathrm{mol}, 6$ mole \%) were successively added within $1 \mathrm{~min}$ under open flask conditions to a stirring suspension of enyne 7 (45.8 mg, $0.1836 \mathrm{mmol}$, 1 equiv. $)^{30}$ in fetal bovine serum $(1 \mathrm{ml})$. The reaction mixture was then stirred vigorously at r.t. for $5 \mathrm{~min}$. Formation of the products was detected by TLC (hexanes:ethyl acetate 80:20, product $R_{F}$ 0.57). The reaction mixture was diluted with water and extracted with diethyl ether $(3 \times)$. The organic fractions were combined and dried over anhydrous $\mathrm{Na}_{2} \mathrm{SO}_{4}$. The mixture was filtered and concentrated in vacuo to yield the crude product which was purified by flash chromatography on silica gel (hexanes:ethyl acetate 15:1, $R_{F} 0.20$ ). An inseparable 5:1 mixture of isomers $\mathbf{1 3}$ and $\mathbf{1 4}$ was obtained as a brownish oil in $64 \%$ yield (39.2 $\mathrm{mg}, 0.117 \mathrm{mmol}$ ) and a small amount of desilylated by-product was also isolated in $6 \%$ yield $(2.7 \mathrm{mg}, 0.010 \mathrm{mmol})$. The spectroscopic characterization data are in agreement with the literature 23,31 .

\section{6,7,12,13-Tetrahydro-5,14-diaza[5]helicinium Trifluoromethanesulfonate (16)}

Procedure to demonstrate reaction development in transformation $\mathbf{1 5} \rightarrow \mathbf{1 6}$. One drop of acetone $(0.01 \mathrm{ml})$ was added directly to the bottom of a RBF containing [Cp*Ru(cod)Cl] $\mathbf{1}$ (1.7 mg, $4.48 \mu \mathrm{mol}, 25$ mole \%). A solution of 2,2'-(ethyne-1,2-diyl)bis(1-(but-3-ynyl)pyridinium)bis(trifluoromethanesulfonate) 15 (10.6 mg, $18.1 \mu \mathrm{mol}, 1$ equiv. $)^{25}$ in $\mathrm{E}$. coli $\mathrm{DH} 5 \alpha$ cell lysate $(1.5 \mathrm{ml})$ was added to the mixture of catalyst and acetone. The resulting solution was stirred at $37{ }^{\circ} \mathrm{C}$. Aliquots $(0.3 \mathrm{ml})$ of the reaction mixture were removed at reaction times of $2.5,5,24$, and $36 \mathrm{~h}$. These aliquots were concentrated in vacuo and analyzed by ${ }^{1} \mathrm{H}$ NMR (Fig. 1).

Procedure for yield determination in transformation $\mathbf{1 5} \rightarrow \mathbf{1 6}$. One drop of acetone $(0.01 \mathrm{ml})$ was added directly to the bottom of a RBF containing [Cp*Ru(cod)Cl] $1(1.6 \mathrm{mg}, 4.28 \mu \mathrm{mol}$, 25 mole \%). A solution of 2,2'-(ethyne-1,2-diyl)bis(1-(but-3-ynyl)pyridinium)bis(trifluoromethanesulfonate) $\mathbf{1 5}$ (10.0 mg, $17.1 \mu \mathrm{mol}, 1$ equiv. $)^{25}$ in E. coli DH5 $\alpha$ cell lysate $(1.5 \mathrm{ml})$ was added to the mixture of catalyst and acetone. The resulting solution was stirred at $37^{\circ} \mathrm{C}$ 
for $36 \mathrm{~h}$. The yield of this reaction was determined by ${ }^{1} \mathrm{H}$ NMR with comparison to DMSO as an internal standard.

Procedure for transformation $\mathbf{1 5} \rightarrow \mathbf{1 6}$ with added bovine serum albumin. One drop of acetone $(0.01 \mathrm{ml})$ was added directly to the bottom of a RBF containing [Cp*Ru(cod)Cl] $\mathbf{1}(0.8 \mathrm{mg}$, $2.14 \mu \mathrm{mol}, 25$ mole \%). A solution of 2,2'-(ethyne-1,2-diyl)bis(1-(but-3-ynyl)pyridinium)bis(trifluoromethanesulfonate) $\mathbf{1 5}(5.0 \mathrm{mg}, 8.6 \mu \mathrm{mol}, 1 \text { equiv. })^{25}$ and bovine serum albumin $(26.4 \mathrm{mg})$ in $\mathrm{E}$. coli $\mathrm{DH} 5 \alpha$ cell lysate $(1 \mathrm{ml})$ was added to the mixture of catalyst and acetone. The resulting solution was stirred at $37{ }^{\circ} \mathrm{C}$ for $36 \mathrm{~h}$. The reaction mixture was concentrated in vacuo. ${ }^{1} \mathrm{H}$ NMR analysis indicates formation of 6,7,12,13-tetrahydro-5,14-diaza[5]helicinium trifluoromethanesulfonate $\mathbf{1 6}$ and consumption of the starting material $\mathbf{1 5}$ (Fig. 2).

\section{Supporting Information Available}

Further analytical data, scanned NMR spectra, and yield determination for transformation in Scheme 5 are available free of charge at http://dx.doi.org/10.1135/cccc2009053.

Support of this work by the Institute of Organic Chemistry and Biochemistry, Academy of Sciences of the Czech Republic, v.v.i. (Z4 0550506 and IOCB Postdoctoral Fellowship to L.A.) and Czech Science Foundation (203/09/0705 and 203/09/1614) is gratefully acknowledged. We thank J. Konvalinka, I. Starý and D. Schröder for stimulating discussions, and M. Kožišek, L. Machala, J. Sedláková and J. Slaninová for experimental help and support.

\section{REFERENCES AND NOTES}

1. Corey E. J., Cheng X.-M.: The Logic of Chemical Synthesis. Wiley, New York 1995.

2. a) Crabtree R. H.: The Organometallic Chemistry of the Transition Metals, 4th ed. Wiley, Hoboken 2005; b) Hegedus L. S.: Transition Metals in the Synthesis of Complex Organic Molecules, 2nd ed. University Science Books, Sausalito 1999.

3. For reviews on C-M bonds in nature, see: a) Kovacs J. A., Shoner S. C., Ellison J. J.: Science 1995, 270, 587; b) Jaouen G. (Ed.): Bioorganometallics. Wiley-VCH, Weinheim 2006; c) Beck W., Severin K.: Chem. Unserer Zeit 2002, 36, 356.

4. Non-catalytic applications of air-, water- and bio-compatible organometallics relevant to chemical biology are documented. For leading references, see: a) Allardyce C. S., Dorcier A., Scolaro C., Dyson P. J.: Appl. Organomet. Chem. 2005, 19, 1; b) Yan Y. K., Melchart M., Habtemariam A., Sadler P. J.: Chem. Commun. 2005, 4764; Also see refs ${ }^{3 \mathrm{~b}, 3 \mathrm{c}}$.

5. For reviews on artificial $\mathrm{C}-\mathrm{C}$ bond formations catalyzed by late transition metals in air and water, see: a) Li C.-J.: Chem. Rev. 2005, 105, 3095; b) Li C.-J., Chan T.-H.: Comprehensive Organic Reactions in Aqueous Media. Wiley, Hoboken 2007; c) Lipshutz B. H., Ghorai S.: Aldrichimica Acta 2008, 41, 59.

6. For leading discussion on the catalytic aspect of bioorganometallic chemistry, see: Streu C., Meggers E.: Angew. Chem. Int. Ed. 2006, 45, 5645.

7. For an example of catalytic hydrogenation of membrane lipids in living systems, see: a) Vigh L., Joó F., Cséplö M.: Eur. J. Biochem. 1985, 146, 241; b) Horváth I., Glatz A., Varvasovszki V., Török Z., Páli T., Balogh G., Kovács E., Nádasdi L., Benkö S., Joó F., Vigh L.: Proc. Natl. Acad. Sci. U.S.A. 1998, 95, 3513. 
8. For a note on CuAAC in human plasma, see: a) Rostovtsev V. V., Green L. G., Fokin V. V., Sharpless K. B.: Angew. Chem. Int. Ed. 2002, 41, 2596; For CuAAC with living cells, see b) Link A. J., Tirrell D. A.: J. Am. Chem. Soc. 2003, 125, 11164.

9. a) Editorial address highlighting the need for non-coded reaction candidates amenable to integration with complex living cell environment, see: Sames D.: Chem. Eng. News 2001, 79, 276; For recent overviews, see: b) Prescher J. A., Bertozzi C. R.: Nat. Chem. Biol. 2005, 1, 13; c) Barglow K. T., Cravatt B. F.: Nat. Methods 2007, 4, 822; d) Kurpiers T., Mootz H. D.: Angew. Chem. Int. Ed. 2009, 48, 1729.

10. For significant work towards this goal, see: a) Lin Y. A., Chalker J. M., Floyd N., Bernardes G. J., Davis B. G.: J. Am. Chem. Soc. 2008, 130, 9642; b) Tilley S. D., Francis M. B.: J. Am. Chem. Soc. 2006, 128, 1080; c) Antos J. M., Francis M. B.: J. Am. Chem. Soc. 2004, 126, 10256; d) McFarland J. M., Francis M. B.: J. Am. Chem. Soc. 2005, 127, 13490; e) Mortell K. H., Gingras M., Kiessling L. L.: J. Am. Chem. Soc. 1994, 116, 12053; f) Dibowski H., Schmidtchen F. P.: Angew. Chem. Int. Ed. 1998, 37, 476; g) Bong D. T., Ghadiri M. R.: Org. Lett. 2001, 3, 2509; h) Ojida A., Tsutsumi H., Kasagi N., Hamachi I.: Tetrahedron Lett. 2005, 46, 3301; i) Liebeskind L. S., Yang H.; Li H.: Angew. Chem. Int. Ed. 2009, 48, 1417; For overview, see: j) Antos J. M., Francis M. B.: Curr. Opin. Chem. Biol. 2006, 10, 253, and references therein.

11. In nature coenzyme $B_{12}$ is known to catalyze $C-C$ bond formations proceeding via organometallic pathways of radical character, see a) Butler P. A., Kräutler B.: Top. Organomet. Chem. 2006, 17, 1; Specifically, anaerobic archebacteria employ methylcobaltamin in conjuction with nickel organometallics in an acetyl-coenzyme A synthasecatalyzed coupling of carbon monoxide with a methyl group to construct a C-C bond in an acetyl moiety, see: b) Ragsdale S. W.: Chem. Rev. 2006, 106, 3317; A related catalytic pathway, involving organometallics under anaerobic aqueous conditions, has been proposed to be the primordial initiation reaction for a chemoautotrophic origin of life, see: c) Huber C., Wächtershäuser G.: Science 1997, 276, 245; d) Crabtree R. H.: Science 1997, 276, 222.

12. For pioneering report, see: Agard N. J., Prescher J. A., Bertozzi C. R.: J. Am. Chem. Soc. 2004, 126, 15046; For an overview, see: Agard N. J., Baskin J. M., Prescher J. A., Lo A., Bertozzi C. R.: ACS Chem. Biol. 2006, 1, 644.

13. a) Wang Q., Chan T. R., Hilgraf R., Fokin V. V., Sharpless K. B., Finn M. G.: J. Am. Chem. Soc. 2003, 125, 3192; b) Speers A. E., Cravatt B. F.: Chem. Biol. 2004, 11, 535; Also see ref. $^{8}$.

14. For an overview of the versatility of catalyst $\mathbf{1}$, see: a) Dérien S., Dixneuf P. H.: J. Organomet. Chem. 2004, 689, 1382; b) Trost B. M., Frederiksen M. U., Rudd M. T.: Angew. Chem. Int. Ed. 2005, 44, 6630, and references therein.

15. For an initial report on this process under anhydrous conditions and inert atmosphere, see: Yamamoto Y., Arakawa T., Ogawa R., Itoh K.: J. Am. Chem. Soc. 2003, 125, 12143.

16. For rare $[2+2+2]$ cycloadditions in presence of $\mathrm{O}_{2}$, see: a) Severa L., Vávra J., Kohoutová A., Čížková M., Šálová T., Hývl J., Šaman D., Pohl R., Adriaenssens L., Teplý F.: Tetrahedron Lett. 2009, 50, 4526; b) Yokota T., Sakurai Y., Sakaguchi S., Ishii Y.: Tetrahedron Lett. 1997, 38, 3923; c) Ardizzoia G. A., Brenna S., LaMonica G., Maspero A., Masciocchi N.: J. Organomet. Chem. 2002, 649, 173; d) Geny A., Agenet N., Iannazzo L., Malacria M., Aubert C., Gandon V.: Angew. Chem. Int. Ed. 2009, 48, 1810; Also see ref. ${ }^{25}$ 
17. For $[2+2+2]$ cycloadditions catalyzed by $\left[\left\{\mathrm{Ru}\left(\eta^{3}: \eta^{3}-\mathrm{C}_{10} \mathrm{H}_{16}\right)(\mu-\mathrm{Cl}) \mathrm{Cl}\right\}_{2}\right]$ in mixtures of $\mathrm{H}_{2} \mathrm{O} / \mathrm{MeOH}$ under $\mathrm{N}_{2}$ atmosphere at $75{ }^{\circ} \mathrm{C}$, see: Cadierno V., García-Garrido S. E., Gimeno J.: J. Am. Chem. Soc. 2006, 128, 15094.

18. For an initial report on this process under anhydrous conditions and inert atmosphere, see: Yamamoto Y., Kinpara K., Ogawa R., Nishiyama H., Itoh K.: Chem.-Eur. J. 2006, 12, 5618.

19. Šálová T.: M.S. Thesis. Charles University, Prague 2008.

20. For an initial report on this process under inert atmosphere in presence of water, see: Dérien S., Jan D., Dixneuf P. H.: Tetrahedron 1996, 52, 5511.

21. For a note on oxygen- and moisture-tolerance of Ru-catalyzed alkene-alkyne coupling, see: Trost B. M., Pinkerton A. B., Toste F. D., Sperrle M.: J. Am. Chem. Soc. 2001, 123, 12504; In spite of this note, the reactions are invariably run under an inert atmosphere, see ref. ${ }^{14 \mathrm{~b}}$; The attractive $\mathrm{O}_{2}$ and $\mathrm{H}_{2} \mathrm{O}$-compatibility of this process remains, to the best of our knowledge, unexplored.

22. For a recent example of aldehyde follow-up reactivity, see: Angelov T., Guainazzi A., Schärer O. D.: Org. Lett. 2009, 11, 661.

23. This process has been recently described to proceed rapidly in presence of water under inert atmosphere, see: Monnier F., Vovard-Le Bray C., Castillo D., Aubert V., Dérien S., Dixneuf P. H., Toupet L., Lenco A., Mealli C.: J. Am. Chem. Soc. 2007, 129, 6037.

24. Preliminary NMR investigation suggests $\mathbf{1 3}$ was obtained as a racemate.

25. Adriaenssens L., Severa L., Šálová T., Císařová I., Pohl R., Šaman D., Rocha S. V., Finney N. S., Pospíšil L., Slavíček P., Teplý F.: Chem.-Eur. J. 2009, 15, 1072.

26. Yield determined by ${ }^{1} \mathrm{H}$ NMR with comparison to DMSO as an internal standard. Details in Electronic Supplementary Data section.

27. Details in Electronic Supplementary Data accompanying this article.

28. a) Williams D. S., Atilla G. E., Bregman H., Arzoumanian A., Klein P. S., Meggers E.: Angew. Chem. Int. Ed. 2005, 44, 1984; For a review, see: b) Melchart M., Sadler P. J. in: Bioorganometallics (G. Jaouen, Ed.), p. 39. Wiley-VCH, Weinheim 2006; Also see refs ${ }^{4 \mathrm{a}, 4 \mathrm{~b}}$; For a recent account, see: c) Gossens C., Tavernelli I., Rothlisberger U.: J. Am. Chem. Soc. 2008, 130, 10921; For excellent overview, see: d) Meggers E.: Curr. Opin. Chem. Biol. 2007, 11, 287.

29. Amabilino D. B., Ashton P. R., Reder A. S., Spencer N., Stoddart J. F.: Angew. Chem., Int. Ed. Engl. 1994, 33, 1286.

30. Gibson S. E., Kaufmann K. A. C., Haycock P. R., White A. J. P., Hardick D. J., Tozer M. J.: Organometallics 2007, 26, 1578.

31. Monnier F., Castillo D., Dérien S., Toupet L., Dixneuf P. H.: Angew. Chem. Int. Ed. 2003, 42,5474 . 